\title{
Mechanical Properties of Artery and Characteristics of Pulse Wave Propagation
}

\author{
正 渡辺 知規（千葉大） ○学 小柳津 圭介（千葉大） \\ Tomonori WATANABE, Chiba University, 1-33, Yayoi-cho, Inage-ku, Chiba-shi, Chiba, 263-8522 \\ Keisuke OYAIZU, Chiba University, 1-33, Yayoi-cho, Inage-ku, Chiba-shi, Chiba, 263-8522 \\ Key Words : Mechanical Properties, Pulse Wave, Nonlinear, Stress-Strain Curve
}

\section{1. 緒言}

近年, 工学的応用に向け, 生体材料の機能に関する研究が 盛んに行われている. 多くの生体材料では，概して，力学的 性質に非線形性を有するために, 解析にあたっては, 取り扱 いが非常に困難となっている. 事実, 代表的な生体材料のひ とつである血管においては, 血管壁の応カーひずみ特性が非線 形性を有し, この非線形性の取り扱いが血管系の解析におい て大きな問題となっている，血管のもつ材料非線形性は，一 般に，脈波の伝播特性に影響を及ぼすとされている.とりわ け，血管の病変部や人工血管部など, 血管壁の力学的性質が 異なる部位を有する血管において，血管壁の力学的性質が脈 波伝播特性に及ぼす影響を明らかにすることは，血管疾患の 検查法の確立に役立つばかりでなく，人工血管を設置する際 の適切な処置法の提案のために重要であるとされている.

本研究では，血管壁の応力ーひずみ特性が有する非線形性 を厳密に取り入れた血管モデルを用いて，血管壁の力学的性 質の異なる部位の存在が, 脈波に及ぼす影響を明らかにする ことを目的とする.

\section{2. 解析手法}

本研究では，血管壁の応カーひずみ曲線として， $\sigma$ を応 カ, $\gamma$ をひずみ, $\sigma_{0}$ と $\gamma_{0}$ を定数としたときに, 実験式 ${ }^{(1)}:$

$$
\sigma=\sigma_{0}\left[\exp \left(\gamma / \gamma_{0}\right)-1\right]
$$

を採用する. この式に，血管長軸方向への一次元ナビェ・ス トークス方程式や連続の式などを用い，さらに，空間の離散 幅を $l$ として，離散化を行うと，血管壁の材料非線形性を厳 密に取り入れた血管モデル (坂西モデル ${ }^{(1)}$ )の方程式として,

$\frac{\mathrm{d}}{\mathrm{d} t^{2}} \log \left(1+\frac{\Delta p_{i}}{a_{i}}\right)=\frac{b_{i}}{m}\left(\Delta p_{i+1}+\Delta p_{i-1}-2 \Delta p_{i}\right)$,

を得ることができる. ここで, $t$ は時間, $i$ は血管の長さ方向 の離散的な位置であり， $\Delta p_{i}$ は最低血圧 $p_{d}$ からの圧力の変化 量を表す. $m$ は，血液の密度を $\rho$ としたときに, $m=2 \rho l^{2}$ として与えられる定数である. また， $a_{i}$ と $b_{i}$ は，血管の半径 を $R_{i}$ ，壁厚を $h_{i}$ としたときに， $a_{i}=\sigma_{0} h_{i} / R_{i}-p_{d}$, およ び, $b_{i}=1 / \gamma_{0}$ として与えられる. ここで, $\Delta \gamma_{i}$ を管半径の ひずみの変化量とすると，血管の内压と $\Delta \gamma_{i}$ との関係として，

$$
\Delta p_{i}=a_{i}\left[\exp \left(b_{i} \Delta \gamma_{i}\right)-1\right]
$$

を得ることができる. よって, 関係式 (3) から, $a_{i}$ と $b_{i}$ の積 (以 下 $\left.a_{i} \cdot b_{i}\right)$ は， $\Delta \gamma_{i}=0$ での傾きを意味し， $b_{i}$ は曲線の非線形 性の度合いを表すことがわかる. したがって, 本研究におい ては，血管壁が有する力学的性質は，二つのパラメータ $a_{i}$ と $b_{i}$ によって表されることがわかる. さらに，本研究では， $a_{i}$ と $b_{i}$ を共に位置 $i$ の関数とおくことにより, 血管壁の力学的 性質の異なる部位を取り扱う. すなわち, 規格化をした $a_{i}$ と $b_{i}$ について，血管にて， $a_{i}=b_{i}=1$ とした部位を正常部とし， $a_{i}=a$ ，およひ， $b_{i}=b$ とした部位を，正常部に対して， 力学的性質が異なる部位である「異質部」として取り扱う.
本研究では， $a$ と $b$ が様々な值をとる場合に，脈波に生じる 変化として，圧脈波 $\Delta p_{i}$ と流速 $\Delta v_{i}$ :

$$
\Delta v_{i}=-\frac{1}{\rho l} \int\left(\Delta p_{i+1}-\Delta p_{i}\right) \mathrm{d} t,
$$

の振舞いについて調べた.

数值解析にあたつては, 非線形方程式 (2)がもつ特徴を応用 した. すなわち，まず，式(2)が，ハミルトン系の方程式であ るという特徵に着目をして, 数值計算法として 6 次のシンプ レクティック法を用いた. シンプレクティック法は, ハミル トン系において，ハミルトニアンをある一定の誤差範囲に保 存するという特長を持つため，長時間挙動を見るのに適した 数值計算法であることが知られている. さらに, 本研究では, 脈波の変化をより明確に捉えるために, 方程式 (2)が厳密解を もつという特徵を応用し, 式 (2)の撖密解であるソリトン解 ${ }^{(2)}$ を脈波の初期值として入力した. ただし, 波数は 0.1 とした.

\section{3. 結果と考察}

力学的性質が異なる部位である「異質部」を有する血管を 伝播する脈波の様子を図1に示す. 図では, 脈波伝播のひとつ の例として， $0 \leq i \leq 199$ の位置を異質部とし， $a=5.0$ ， および, $b=1.0$ とした. 脈波の振幅としては, 入力波の振 幅を $(\Delta p)_{\text {in }}$ としたときに，入力波の振幅の大きさが1となるよ うに規格化を行った. 図から，血管を伝播する脈波は，正常 部から，異質部に入る時 $(t \approx 60)$ たけでなく，異質部から 正常部に出る時（ $t \approx 150)$ にも反射波を発生させることが わかる. また，異質部内では，波の振幅と幅が，入射波とは 大きく異なり，異質部を透過した後も，入射波とは振幅や波 形が変化している.

異質部と正常部の境界での振舞いをさらに詳しく調べるた めに，図1と同じ条件のもとで，正常部から異質部に入射する 脈波の様子を図2に示す. 図中太線は，時間の変化に伴う脈波 の頂点の位置の軌跡を表す. 図から, 脈波の振幅の急激な変 化は, 脈波の頂点が異質部に入る $t=40$ のあたり, すなわち, 境界手前付近から起こっていることがわかる. また, $t=60$ では，反射波が発生している．同様の傾向は，異質部から正 常部となる出口側の境界においても見られた

脈波の反射波が，異質部の力学的性質を表す $a$ と $b$ に, ど のように依存するのかを明らかにするために, $a$ と $b$ を変化 させた場合において，異質部の入りロ $i=0$ から離れた位置 $i=-200$ での，圧脈波と流速における反射波の振幅の大き さを図3に示す．まず，図から，圧脈波と流速のいずれの場合 においても， $a$ と $b$ に対する反射波の振幅の依存性は同じ，す なわち，反射波の振幅の大きさは，ほぼ， $a \cdot b$ の值に依存し ていることがわかる. また, 圧力波では, $a \cdot b$ が1以下で負 の振幅の反射波を発生させ, $a \cdot b$ が1以上で正の反射波を発 生させる. 一方, 流速では, 圧力波と全く逆の振舞いをする.

つぎに, $a$ と $b$ を変化させた場合において, 異質部透過後 ( $i=400)$ の圧脈波の振幅の大きさを図4に示す. 図から, 異質部の $a$ と $b$ 違いにより振幅が大きく変わっていること がわかる. $a \cdot b$ が極端に1より大きい場合と, 極端に小さい 


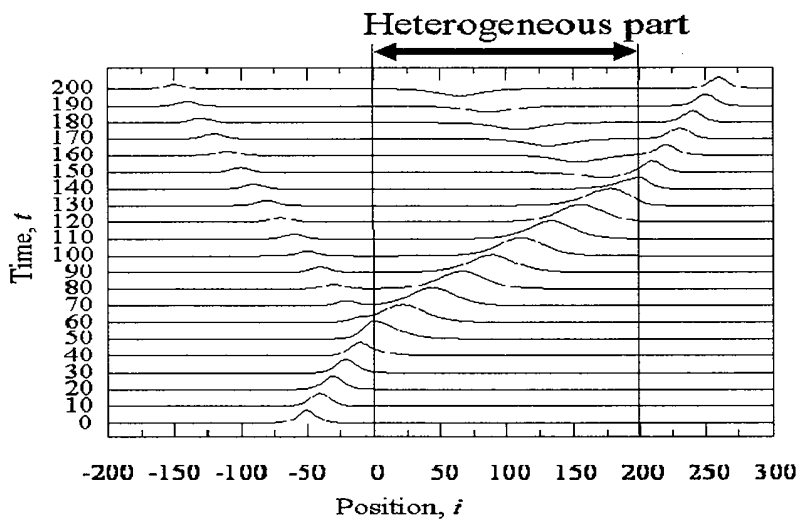

Fig. 1 Propagation of the pressure wave ( $a=5.0$ and $b=1.0$ ).

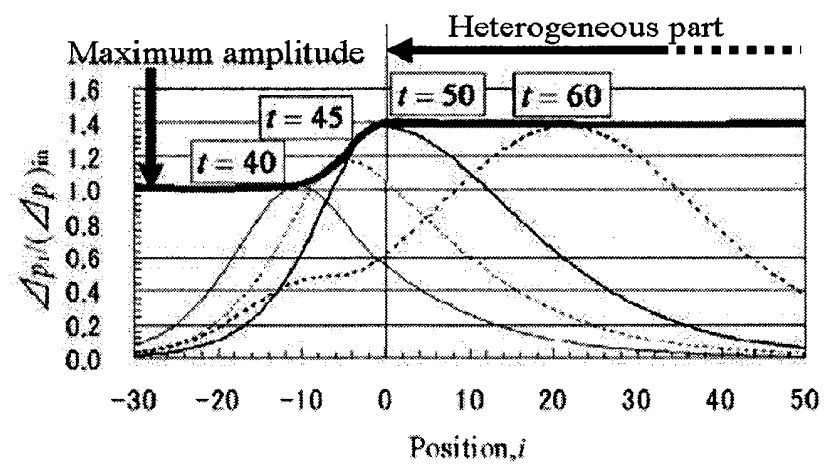

Fig. 2 Behavior of the pressure wave around the boundary $(a=5.0$ and $b=1.0)$.

場合では，ほとんど $a \cdot b$ の值のみに依存している，しかし， $a \cdot b$ が比較的1に近い領域においては， $b$ が大きく（ $a$ が小 さく）なるにつれ，異質部透過後の振幅は，入力波形よりも 大きくなることがわかる. 実際に，この場合での脈波の様子 を図5に示す，図5から，異質部中では，脈波の振幅が伝播と 共に大きくなっていることがわかる. この傾向は、血管壁の 応カーひずみ曲線の非線形性の度合いを表す $b$ が大きい場合 のみに見られた．したがって，異質部透過後の振幅は，異質 部での血管壁の非線形性の影響を大きく受けるということが わかる，また，図5から，非線形性が大きい場合には，振幅が 大きくなるにともない，波形が急峻になることがわかる．こ のような波形の変化は，流速においても同様に見られた.

\section{4. 結言}

血管壁の材料非線形性を厳密に取り入れた血管モデルを用 いて，血管に存在する力学的性質の異なる部位が脈波に及ぼ す影響について検討した，得られた主な結果を以下に記す。

1.力学的性質の異なる部位の影響で，脈波には，主に，つぎ の4つの变化が生じる．i）正常部と異質部との境界（入り 口側と出口側) で反射波が発生する. ii）正常部から異質 部，および，異質部から正常部に脈波が伝播する際には， 振幅等に変化が生じ, 変化は境界手前付近から起こる. iii) 異質部内では，脈波は，入射波とは異なった振幅と幅をも って伝播する. 特に，異質部の力学的性状によっては，波 形を変化させながら伝播する．iv）概して，異質部透過後 の振幅や波形は入力波とは異なる。

2. 正常部と異質部との境界で発生する反射波の振幅に影響 を与える主な因子は，圧カ-半径曲線の原点での傾き $a \cdot b$

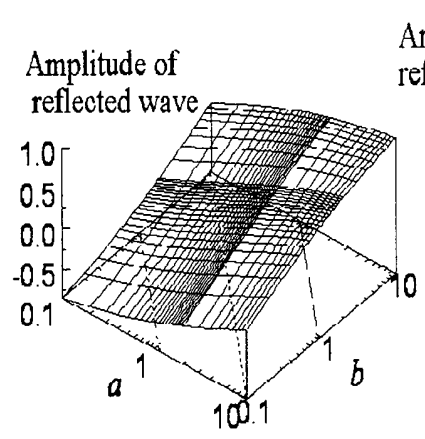

(a)Pressure wave
Amplitude of Contour lines reflected wave

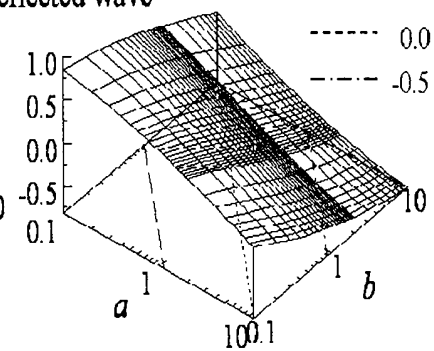

(b)Flow velocity
Fig. 3 Relations between the amplitude of the reflected wave and the parameters ( $a$ and $b$ ) at $i=-200$.

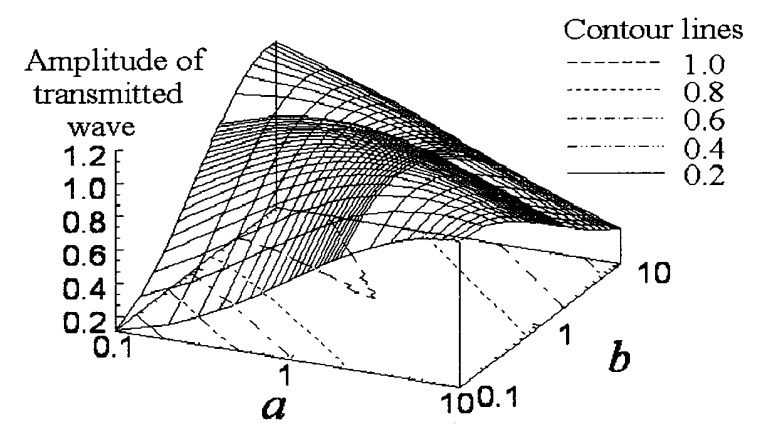

Fig. 4 Relation between the amplitude of the transmitted wave and the parameters ( $a$ and $b$ ) at $i=400$.

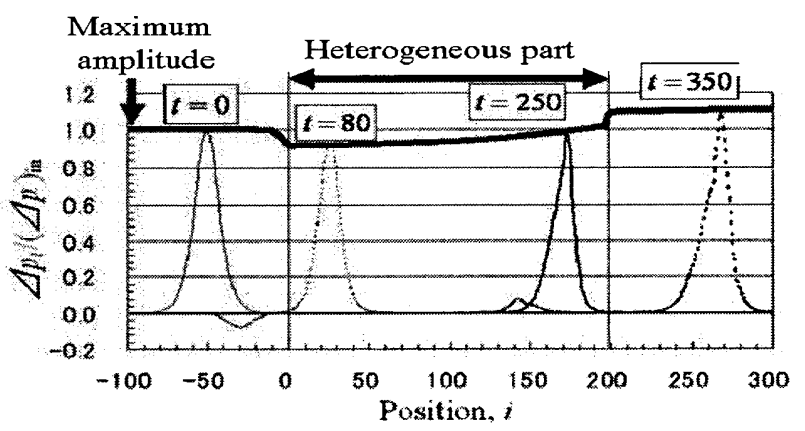

Fig. 5 Propagation of the pressure wave at each time $t$ $(a=0.1$ and $b=7.0$ ).

である.

3. $a \cdot b=1$ の条件を満たすとき，圧力波と流速にはともに， 反射波がほとんど発生しない，圧力波では， $a \cdot b>1$ で正 の振幅， $a \cdot b<1$ で負の振幅の反射波が発生する．流速に おいては， $a \cdot b>1$ で負の振幅， $a \cdot b<1$ で正の振幅の反 射波が発生する。

4. 異質部透過後の振幅は, 異質部の $a$ と $b$ の值に大きく依存 する. 特に，血管壁の応力ーひずみ曲線の非線形性を表す $b$ の值によって, 振幅の大きさや波形の変化がもたらされる.

5. 血管壁の応力ーひずみ曲線の非線形性を表す $b$ が大きくな ると脈波の振幅が大きくなり，波形の立ち上がり傾斜が急 峻になる。

\section{5. 参考文献}

(1) Sakanishi, et al, Physics Letters A, No.221(1996), 395.

（2）渡辺慎介，ソリトン物理入門，培風館，（1985）。 